\title{
Book News
}

Patrick J. Wilkinson

The Rise and Fall of the People's Century: Henry A. Wallace and American Liberalism 1941-1948, by Norman D. Markowitz. New York: The Free Press, 1973, pp. xi, 369.

IN THIS VOLUME NORMAN D. MARKOWITZ traces the failure of Henry A. Wallace and American liberalism during World War II and the nascent Cold War to implement an effective liberal program for post-war America and a world racked by war. Wallace, as the leading spokesman for American liberalism during the war, did construct such a program. This "People's Century" called for a New Deal world; a world made secure by peace and abundance. Yet this fantasy of a "People's Century" never became reality because Wallace and American liberalism proved unequal to the task. Markowitz points out that liberals were a captive part of the New Deal coalition and largely mesmerized with the personality cult of Franklin Roosevelt. When FDR died and tension between the United States and the Soviet Union increased, liberals faded into ineffectual protest or became "Vital Center" liberals accepting a militarized foreign policy and petty domestic reform.

Markowitz places Wallace's failure, symbolized by his futile campaign and defeat for President in 1948, in historical perspective. Wallace's family, agrarian, and religious background combined with American liberal thought, which Markowitz finds to be superficially optimistic and full of contradictions, produced in Henry Wallace the idea of a cooperative commonwealth where capitalists would gladly eschew profits for the common good and world peace. This idea was obviously based more on Wallace's good will than good'sense.

Yet Markowitz doesn't paint Wallace as a well intentioned fool. 
In fact, Markowitz's purpose in writing this book is to correct such stereotypes of Henry A. Wallace. In the "Preface" the author comments, "In writing about Henry Wallace ... historians especially have shown themselves to be captives of the present and its stereotypes when they have sought to write about the recent past." Thus the images of Wallace as a Communist dupe, tragic figure, personal eccentric and mystic, or Open Door imperialist are shattered by Markowitz's pen as he portrays Wallace as a man of intelligence and compassion trying to create a "People's Century"-a century where peace would reign through international cooperation; prosperity would flourish through expanded world trade; domestic reform would be realized through economic democracy; and domestic freedom would be insured by respect for the civil liberties of all, even Communists.

But as Markowitz demonstrates, this vision was smashed by forces that Wallace could not control or defeat. The failure of FDR and the New Deal to transform the Democratic Party into a liberal-labor alliance left the party in the hands of big-city machines and Southern politicians who opposed Wallace and his program at every turn. The increasing conservative strength in the Congress accentuated by President Truman's lack of leadership blocked most meaningful social legislation in the early post-war era. And finally the tensions of the Cold War engendered such an atmosphere of militant hate and suspicion that anyone who advocated cooperation with the Soviet Union seemed to mouth virtual treason. These swirling currents caught Wallace and his dream in a fatal undertow.

The years 1941-1948 are a dramatic and important segment in America's history. Certainly Markowitz's book reflects the drama and import of these years. Moreover to the author's credit, he refuses to canonize Henry Wallace. Markowitz's sympathy for Wallace is open but so is his criticism. The shallowness of much of Wallace's thinking is detailed along with Wallace's retreat to the Cold War consensus after the start of the Korean War. Yet in the Henry Wallace of the 1940's, Markowitz recognizes an admirable man. According to Markowitz, Wallace came to grips with the basic problems of American society; and even though his solutions were imperfect, they were far better than the policies actually followed.

$$
\text { \# \# }
$$


Copyright of Annals of Iowa is the property of State of Iowa, by \& through the State Historical Society of Iowa and its content may not be copied or emailed to multiple sites or posted to a listserv without the copyright holder's express written permission. However, users may print, download, or email articles for individual use. 